\title{
Dry Sliding Wear Properties of a 7075-T6 Aluminum Alloy Coated with Ni-P (h) in Different Pretreatment Conditions
}

\author{
Jothi Sudagar, K. Venkateswarlu, and Jainshe Lian
}

(Submitted April 25, 2009; in revised form June 30, 2009)

\begin{abstract}
Dry sliding wear behavior of electroless nickel-phosphorus (EN) coating of thickness $\sim 35 \mu \mathrm{m}$ deposited on a 7075-T6 aluminum alloy was studied. EN was deposited from a bath with sodium hypophosphite as a reducing agent. In as-deposited conditions, plating with 6-9 wt.\% phosphorus has a mixture of amorphous and microcrystalline phase. Three pretreatments of $\mathrm{Zn}$ (zincate), Ni strike and absorbed hypophosphite layer were given to the substrate before EN coating to examine their wear performance. The surface morphology of the pretreatments was studied by a confocal laser scanning microscope. The performances of these pretreatments of EN were evaluated by dry sliding wear studies and followed by SEM studies. The results suggest that the wear behavior of EN mostly depends on the pretreatment conditions. Heat treatment at temperature of $400{ }^{\circ} \mathrm{C}$ can enhance the wear resistance properties for all types of pretreatment conditioned samples and in addition that the average coefficient of friction of $400{ }^{\circ} \mathrm{C}$ specimens $\left(\mu_{\mathrm{av}}\right) \mathrm{had}$ minimum value as compared to $200{ }^{\circ} \mathrm{C}$ specimens. Ni strike provided better interlocking adhesion between $\mathrm{EN}$ and $\mathrm{Al}$ and this pretreatment noticeably improved the wear, frictional and hardness behavior of the EN coatings on 7075 Al substrate and further enhanced it by heat treatment of $400{ }^{\circ} \mathrm{C} / \mathrm{h}$.
\end{abstract}

Keywords aluminum alloy, electroless, pretreatment, wear

\section{Introduction}

Electroless plating refers to the autocatalytic or chemical reduction of aqueous metal ions coated to a base substrate without applying an external electric voltage (Ref 1-3). Electroless deposition can also provide a protective coating for common metal surfaces (Ref 4, 5). In general, an electroless nickel-phosphorus (EN) deposit is less porous and more uniform than an equivalent electrolytically plated deposit, and thus provides better corrosion and wear protection (Ref 6,7 ) and is considered as the most simplest and economic method to coat on steel, aluminum, copper, plastics and many other materials. Suitable heat-treatment processes can further enhance the hardness and wear resistance of EN deposits. In general, heat-treatment temperature of $400{ }^{\circ} \mathrm{C}$ results optimum hardness and wear resistance properties and are similar to 'hard' chromium deposits (Ref 8). The performance of EN deposits can also be enhanced through the co-deposition of inert particles such as polytetrafluoroethylene (PTFE), silicon carbide or boron nitride (Ref 9) forming a composite coating. Ramalho and Miranda (Ref 10) have closely examined the influence of PTFE on the sliding and friction properties of Ni-P coated. This investigation showed that the introduction of

Jothi Sudagar and Jainshe Lian, Department of Material Science and Engineering, Key Laboratory of Automobile Materials, Jilin University, Nanling Campus, Changchun 130025, China; and K. Venkateswarlu, Materials Science Division, National Aerospace Laboratories, Bangalore 560 017, India. Contact e-mails: sendme2sudagar@gmail.com and lianjs@jlu.edu.cn.
PTFE particles in the electroless Ni-P coatings produces a significant rise in the wear resistance. Wear properties of electroless Ni-P coatings are related mainly to their phosphorus content and microstructural details. In addition, low phosphorous has better wear resistance compared to high phosphorous coatings and other mechanical property (Ref 11). But the pretreatment of $\mathrm{EN}$ on $\mathrm{Al}$ alloys has more influence in wear properties.

The paramount importance of better mechanical properties depends on the pretreatment of the alloy prior to coating. Moreover, all aluminum alloys are extremely susceptible to the formation of instantaneous oxide layer and results in an unattractive appearance with inferior mechanical properties. However, the electroless plating on aluminum alloys meets many challenges in the processing of plating and research on this topic is scanty. Attempts have been made to study the dry sliding wear behavior of different pretreated condition of 7075 Al alloy. The latter is a very important engineering material and widely employed in aerospace industry for the manufacturing of different components due to its high strength-to-weight ratio and other superior physical and mechanical properties (Ref 12).

The most difficult part of plating on aluminum is to develop an appropriate pretreatment process. The most widely used pretreatment processes for plating on $\mathrm{Al}$ alloys are nickel strike, zinc immersion (zincate) and adsorbed hypophosphite (HP) layers (Ref 13). The present investigation is aimed to study the dry sliding wear and frictional properties of an EN coating with three different types of pretreatments on a high-strength 7075T6 aluminum alloy. The effects of different pretreatments including zinc, nickel and hypophosphite immersion on wear resistance have been investigated while the other processing conditions for electroless coating are unchanged. A dry sliding pin-on-disc wear test method (ASTM G99) is employed to investigate the wear resistance of the coated samples under various test conditions. The $3 \mathrm{D}$ surface morphology of 
pretreatment (without EN) is studied under a confocal laser scanning microscope (LEXT-OLS 3000). The wear performance of these coated samples is discussed in the light of SEM/ EDAX (JEOL, JSM 840A) studies.

\section{Experimental Details}

\subsection{Material Preparation}

A high-strength 7075-T6 aluminum alloy of the following composition (Table 1) was selected for the present study. The sample size was $40 \times 6 \times 6 \mathrm{~mm}$. It is well known that the deposition of EN coating without any pretreatment on $\mathrm{Al}$ alloys is very difficult due to the presence of a thin oxide layer and so an appropriate surface preparation (polishing, degreasing, etching and pretreatment) is required. The substrate was mechanically polished with fine $\mathrm{SiC}$ paper (grit size 1000) before different pretreatment processes. After polishing, the substrate was degreased in sodium carbonate and sodium phosphate, and soils and oils were removed. And then the surface was etched and it was rinsed thoroughly in deionized water. Furthermore, the three aluminum alloy samples were immersed in three separate pretreatment baths, where any one of the $\mathrm{Zn}, \mathrm{Ni}$ and $\mathrm{HP}$ were the main constituents. After being

Table 1 Compositions of 7075-T6 aluminum alloy (in wt.\%)

\begin{tabular}{ccccccccc}
\hline $\mathbf{Z n}$ & $\mathbf{M g}$ & $\mathbf{C u}$ & $\mathbf{F e}$ & $\mathbf{S i}$ & $\mathbf{M n}$ & $\mathbf{C r}$ & $\mathbf{T i}$ & Al \\
\hline 5.96 & 2.57 & 1.88 & 0.3 & 0.11 & 0.15 & 0.23 & 0.03 & Balance \\
\hline
\end{tabular}

pretreated in a separate bath, the sample was immersed in the same electroless bath solution for plating Ni-P deposition layer. The electroless solution was put in a $500-\mathrm{mL}$ glass beaker, which was kept at constant temperature by a thermostat. The bath composition and all operation parameters for the three separate pretreatment and electroless Ni-P deposition are listed in Table 2.

\subsection{Pretreatments}

Three different pretreatments were done separately on three samples under the following conditions:

- Ni strike. The nickel immersion plating solution contained hydrogen fluoride, nickel salts and boric acid. The process was kept for $1 \mathrm{~min}$ at room temperature. A thin film of $\mathrm{Ni}$ was produced on aluminium alloy by contact reduction type reaction between substrate and nickel salt solution. The Ni nucleus on the aluminium substrate effectively produced and acts as a catalyst for the succeeding electroless Ni-P plating.

- Zinc immersion (zincate). The zinc immersion plating solution contained sodium hydroxide, zinc sulphate and sodium potassium tartarate. The process was kept for $1 \mathrm{~min}$ at room temperature. A thin film of $\mathrm{Zn}$ was produced on aluminium alloy and it protects the aluminum against re-oxidation. The zinc precoating tends to sacrifice itself during the Ni-P depositing due to the sacrificial corrosion of zinc.

- Hypophosphite absorbed layer. The hypophosphite absorbed pretreatment solution contained sodium hypophosphite and lactic acid at $\mathrm{pH} 4.5$. The process was kept for $5 \mathrm{~min}$ at $80{ }^{\circ} \mathrm{C}$ temperature. A thin film of $\mathrm{HP}$ was produced on aluminum alloy and it acts as a catalyst for the succeeding electroless Ni-P plating.

Table 2 Composition and operating conditions of degreasing, etching and electroless Ni-P baths for 7075-T6 aluminum alloy

\begin{tabular}{|c|c|c|c|c|}
\hline Process & Operation & Plating bath composition & $(/ \mathbf{L})$ & Condition \\
\hline 1 & Grinding & No. $1000 \mathrm{SiC}$ sandpaper & & \\
\hline 2 & Degreasing bath & $\begin{array}{l}\mathrm{Na}_{2} \mathrm{CO}_{3} \\
\mathrm{Na}_{3} \mathrm{PO}_{4} \cdot 12 \mathrm{H}_{2} \mathrm{O}\end{array}$ & $\begin{array}{l}10 \mathrm{~g} \\
50 \mathrm{~g}\end{array}$ & $65^{\circ} \mathrm{C}$ for $2 \mathrm{~min}$ \\
\hline 3 & Etching bath & $\begin{array}{l}\text { Conc. } \mathrm{H}_{2} \mathrm{SO}_{4} \\
\mathrm{H}_{3} \mathrm{PO}_{4} \\
\text { DM water } \\
\text { Propionic acid, } \mathrm{C}_{3} \mathrm{H}_{6} \mathrm{O}_{2} \\
\text { Distilled with deionized water }\end{array}$ & $\begin{array}{l}40 \mathrm{~mL} \\
20 \mathrm{~mL} \\
40 \mathrm{~mL} \\
0.1 \mathrm{~mL}\end{array}$ & $65^{\circ} \mathrm{C}$ for $2 \mathrm{~min}$ \\
\hline $4 a$ & Pretreatment bath for $\mathrm{Zn}$ (zincate) & $\begin{array}{l}\mathrm{NaOH} \\
\mathrm{ZnSO}_{4} \cdot 7 \mathrm{H}_{2} \mathrm{O} \\
\text { Sodium potassium tartarate }\end{array}$ & $\begin{array}{l}400 \mathrm{~g} \\
120 \mathrm{~g} \\
06 \mathrm{~g}\end{array}$ & Room temperature for $1 \mathrm{~min}$ \\
\hline $4 b$ & Pretreatment bath for Ni strike & $\begin{array}{l}\mathrm{NiSO}_{4} \cdot 7 \mathrm{H}_{2} \mathrm{O} \\
\mathrm{HF}, 40 \% \\
\mathrm{H}_{3} \mathrm{BO}_{3}\end{array}$ & $\begin{array}{l}28 \mathrm{~g} \\
90 \mathrm{~g} \\
40 \mathrm{~g}\end{array}$ & Room temperature for $1 \mathrm{~min}$ \\
\hline $4 c$ & Pretreatment bath for absorbed HP adlayer & $\begin{array}{l}\mathrm{NaH}_{2} \mathrm{PO}_{2} \cdot \mathrm{H}_{2} \mathrm{O} \\
\text { Lactic acid, } 80 \%, \mathrm{C}_{3} \mathrm{H}_{6} \mathrm{O}_{3}\end{array}$ & $\begin{array}{l}30 \mathrm{~g} \\
20 \mathrm{~mL}\end{array}$ & $80{ }^{\circ} \mathrm{C}$ at $\mathrm{pH} 4.5$ for $5 \mathrm{~min}$ \\
\hline 5 & Electroless Ni-P & $\begin{array}{l}\mathrm{NiSO}_{4} \cdot 6 \mathrm{H}_{2} \mathrm{O} \\
\mathrm{NaH}_{2} \mathrm{PO} \cdot \mathrm{H}_{2} \mathrm{O} \\
\mathrm{C}_{2} \mathrm{H}_{5} \mathrm{NO}_{2} \\
\mathrm{C}_{3} \mathrm{H}_{6} \mathrm{O}_{3} \\
\mathrm{C}_{3} \mathrm{H}_{6} \mathrm{O}_{2} \\
\mathrm{CuSO}_{4}{ }^{-} \\
\mathrm{CH}_{3} \cdot \mathrm{COO}\left(\mathrm{Pb}^{-}\right) \cdot 3 \mathrm{H}_{2} \mathrm{O} \\
\text { Distilled with deionized water }\end{array}$ & $\begin{array}{l}0.1 \mathrm{~mol} \\
0.35 \mathrm{~mol} \\
0.09 \mathrm{~mol} \\
0.40 \mathrm{~mol} \\
0.02 \mathrm{~mol} \\
04 \mathrm{ppm} \\
01 \mathrm{ppm}\end{array}$ & $85^{\circ} \mathrm{C}$ at $\mathrm{pH} 6$ for $120 \mathrm{~min}$ \\
\hline
\end{tabular}


After the different pretreatments, the samples were put into the same EN bath for $120 \mathrm{~min}$. The chemical composition and operating baths' parameters are followed as in Table 2. The bath temperature was kept at $85{ }^{\circ} \mathrm{C}$ with a $\mathrm{pH}$ 6. After Ni-P deposition, the three different pretreated EN samples were heattreated at $200{ }^{\circ} \mathrm{C}$ for $1 \mathrm{~h}$ and another three samples were treated at $400{ }^{\circ} \mathrm{C}$ for $1 \mathrm{~h}$, followed by furnace cooling.

\subsection{Dry Sliding Wear}

The dry sliding wear tests were performed using a pin-ondisk type machine (Model TR 20, Ducom, Bangalore, India) in conformity with the ASTM G 99 standard. The stationary pin is 7075 aluminum alloy with different pretreated EN coatings, and the rotating disk is hardened die steel with Rc65 hardness. Figure 1 shows the dimensions of the disc and specimen. Wear tests were carried out under dry sliding conditions under a normal weight of $0.25 \mathrm{~kg}, 0.5 \mathrm{~kg}$ at a sliding speed of $200 \mathrm{rpm}$. A fixed wear track diameter of $80 \mathrm{~mm}$ was used for all the tests, so the sliding distance per second is $200 \mathrm{rpm} \times 2 \pi \times 0.04 \mathrm{~m} /$ $60 \mathrm{~s}=0.84 \mathrm{~m} / \mathrm{s}$. The wear loss was measured directly as the height loss of the specimen using LVDT. Friction coefficient and frictional force were also continuously monitored and recorded separately using WINDCOM 2007 software during each test. The variation in temperature of the specimen surface during the sliding wear tests was measured by inserting a thermocouple through a hole of the stationary pin specimen (test sample) and positioned as close to the contact surfaces as possible.

\subsection{Friction and Hardness}

Frictional properties of electroless nickel coatings ultimately are dependent on the pretreatment and also vary with phosphorus content or with heat treatment. Their phosphorus content provides a natural lubricity, which can be very useful for applications such as plastic moulding. The friction coefficient and frictional force were also continuously monitored and recorded separately during each sliding test. The friction coefficient, $f$, was calculated from the equation: $f=T / L r$, where $T$ is the induced friction torque, $L$ is the normal load and $r$ is the mean contact radius of the rotating pin specimen.

Vickers microhardness test was performed in order to determine the hardness of coating and uncoated samples under a load of $100 \mathrm{~g}$ with a time period for $30 \mathrm{~s}$.

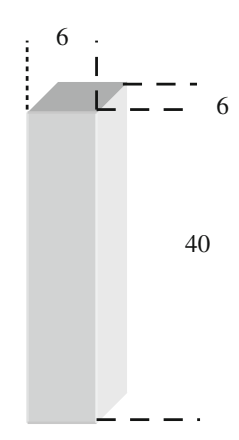

Upper (pin) specimen

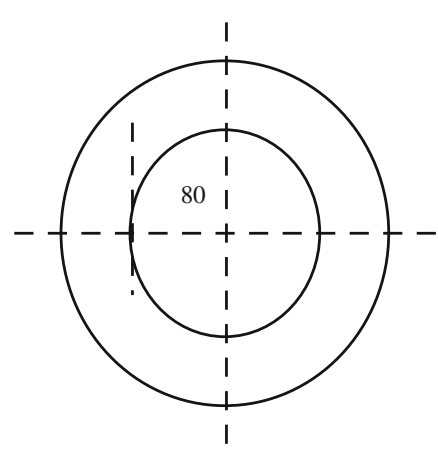

Lower (disc) specimen
All units in mm

Fig. 1 Dimensions of the upper (pin) and lower (disc) specimen

\subsection{Surface Morphology Studies}

The 3D surface morphology of pretreatment (without EN) is studied under confocal laser scanning microscope (LEXT-OLS 3000, Olympus, Japan). The wear track performance and heat treatment of these coated samples is examined using SEM (JEOL, JSM 840A, Japan). The compositional analyses were analyzed by SEM attached kevex energy dispersive $\mathrm{x}$-ray (EDAX).

\section{Results and Discussion}

\subsection{Sliding Wear and Hardness}

The dry sliding wears response of $\mathrm{Al}$ and EN/Al on hardened die steel for different applied loads $(0.25$ and $0.5 \mathrm{~kg})$ is shown in Fig. 2. A sliding distance of about $750 \mathrm{~m}$ (or $900 \mathrm{~s}$ ) is selected in consideration of the coatings thickness. The 7075 Al specimen suffered a wear loss of $\sim 50$ and $\sim 100 \mu \mathrm{m}$ for 0.25 and $0.5 \mathrm{~kg}$ load, respectively. The $7075 \mathrm{Al}$ alloy is (hardness $150 \mathrm{VHN}$ ) relatively soft in comparison to the counter disc and hence exhibited appreciable adhesion and resulted in substantial material removal. The prime cause for material removal under high applied load is attributed to high adhesion between the opposing surfaces, which is possibly due to high ratio of adhesion force to contact force. The strong adhesion force can be explained by the electron transfer between contacting surfaces. Numerous free electrons are present in metals and on contact these electrons may be exchanged between the two solids to establish bonding almost instantaneously (Ref 14). The wear loss was higher in the case of the as-cast Al specimen which slid against disc under different applied loads. The high wear loss in the initial stages was possibly due to high localized contact pressure at the real contact point between the opposing asperities; and with increasing sliding distance the area of the contact surfaces increased after having slid a certain distance. The abrupt increase in initial value was due to the sudden contact of surface of the sample and the counter surface in addition with load and adhesion are also in phase. Hence, the wear loss is initially high.

The wear loss curves of EN/HP/Al, EN/Zn/Al and EN/Ni/ $\mathrm{Al}$ at $200{ }^{\circ} \mathrm{C}, 0.25 \mathrm{~kg}$ condition (Fig. 2a) showed that the sequence of better wear resistance is $\mathrm{EN} / \mathrm{Ni} / \mathrm{Al}, \mathrm{EN} / \mathrm{Zn} / \mathrm{Al}$, and $\mathrm{EN} / \mathrm{Ni} / \mathrm{Al}$ combinations. This negative wear is suggestive of the fact that the increase in specimen height resulted in the specimen being raised from the counter surface. During the dry sliding it was observed that the counter disc suffered wear due to relatively harder Ni-P (h) specimen being slid against it. After having slid a critical sliding distance $(\sim 160 \mathrm{~m}$ or $200 \mathrm{~s}$ ), there is a steady increase in wear loss. The results are similar to the case of a hard diamond composite coating which exhibited such negative wear loss (Ref 15). Consequently, the coating showed a very low wear rate as the pulled out fine particles provided less damage to the EN coated and also the debris were finer and less. Specimens heat treated at $400{ }^{\circ} \mathrm{C}$ can further enhance their wear resistances (Fig. 2b). The heat treatment at $400{ }^{\circ} \mathrm{C}$ enhances the micro-crystalline structure phase in the $\mathrm{EN}$ deposit and thus increases of hardness, so a further enhanced negative wear and improvement in wear properties are observed. This concluded that 400 ${ }^{\circ} \mathrm{C}$ is good heat-treatment temperature for enhancing the wear resistance. 

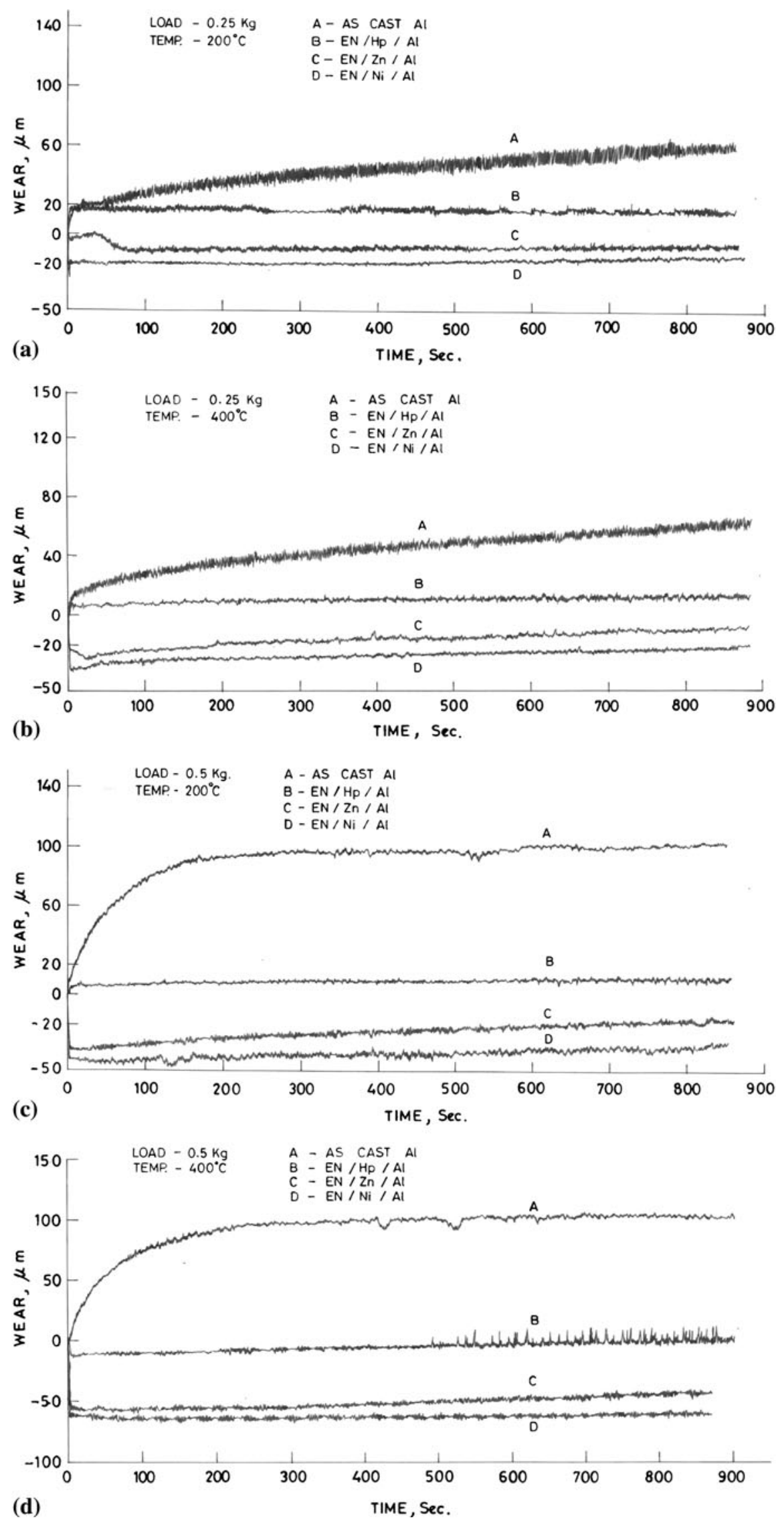

Fig. 2 (a-d) Wear in microns as a function of sliding time when as-cast Al, EN/Zn/Al, EN/HP/Al, EN/Ni/Al specimens slid against stainless steel disc 
The specimens at $200{ }^{\circ} \mathrm{C}, 0.5 \mathrm{~kg}$ condition (Fig. 2c) observe that height increase is possible due to the debris formed during the sliding test adheres to the specimen and responsible for the specimen height. This is also obvious from the fact that though wear damage is higher at higher load $(0.5 \mathrm{~kg})$, negative wear is still high. Since adhesion is stronger under higher loads, the negative wear for $0.5 \mathrm{~kg}$ was greater than at $0.25 \mathrm{~kg}$ load. In addition, the ductile cleavage and deeper grooves were observed in the wear track path of as-cast Al alloy. This was further confirmed by the detachment of counter disc debris and this shows the higher load $(0.5 \mathrm{~kg})$ increases the anti-wear

Table 3 Friction co-efficient of electroless Ni-P (h) deposits in same load $(0.5 \mathrm{~kg})$ condition obtained at different temperature after a sliding time of $800 \mathrm{~s}$

\begin{tabular}{|c|c|c|}
\hline \multirow[b]{2}{*}{$\begin{array}{l}\text { Different } \\
\text { pretreatment }\end{array}$} & \multicolumn{2}{|c|}{ Average co-efficient of friction ( $\mu_{\mathrm{av}}$ ) (a) } \\
\hline & $\begin{array}{c}\text { Ni-P (h) heat } \\
\text { treated at } 200^{\circ} \mathrm{C} / 1 \mathrm{~h}\end{array}$ & $\begin{array}{c}\mathrm{Ni}-\mathrm{P}(\mathrm{h}) \text { heat } \\
\text { treated at } 400^{\circ} \mathrm{C} / 1 \mathrm{~h}\end{array}$ \\
\hline Absorbed HP adlayer & 0.610 & 0.582 \\
\hline Zn (zincate) & 0.523 & 0.376 \\
\hline Ni strike & 0.445 & 0.240 \\
\hline
\end{tabular}

(a) Average of three determinations properties. The specimens at $400{ }^{\circ} \mathrm{C}, 0.5 \mathrm{~kg}$ condition (Fig. $2 \mathrm{~d}$ ) observe that the higher load, optimum temperature enhanced all EN deposits in negative wear properties. It recorded maximum
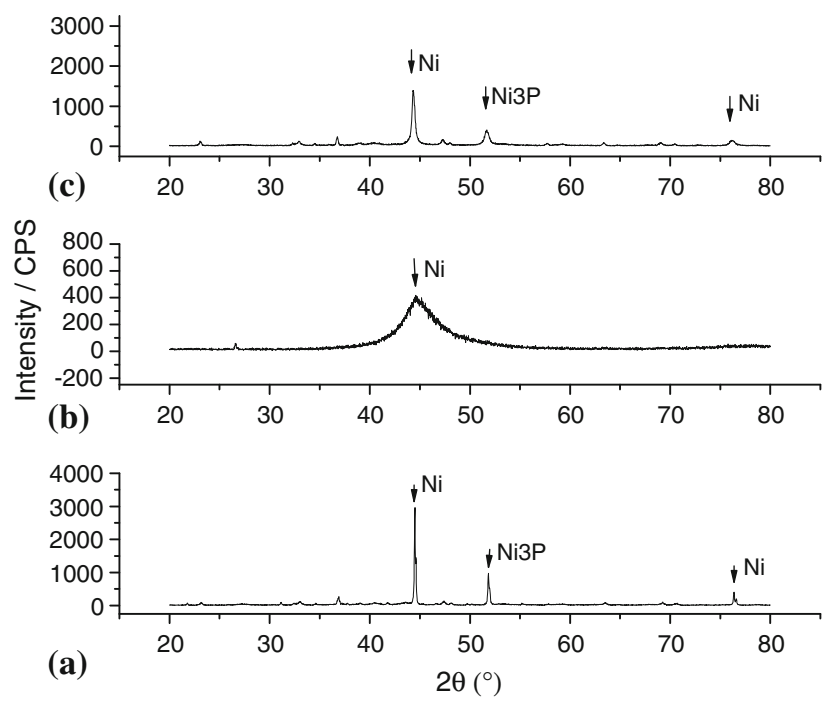

Fig. 4 XRD patterns of the electroless Ni-P deposits at different intervals: (a) Ni-P deposit at $400{ }^{\circ} \mathrm{C} / \mathrm{h}$, (b) as-deposit condition, and (c) Ni-P deposit at $200{ }^{\circ} \mathrm{C} / \mathrm{h}$
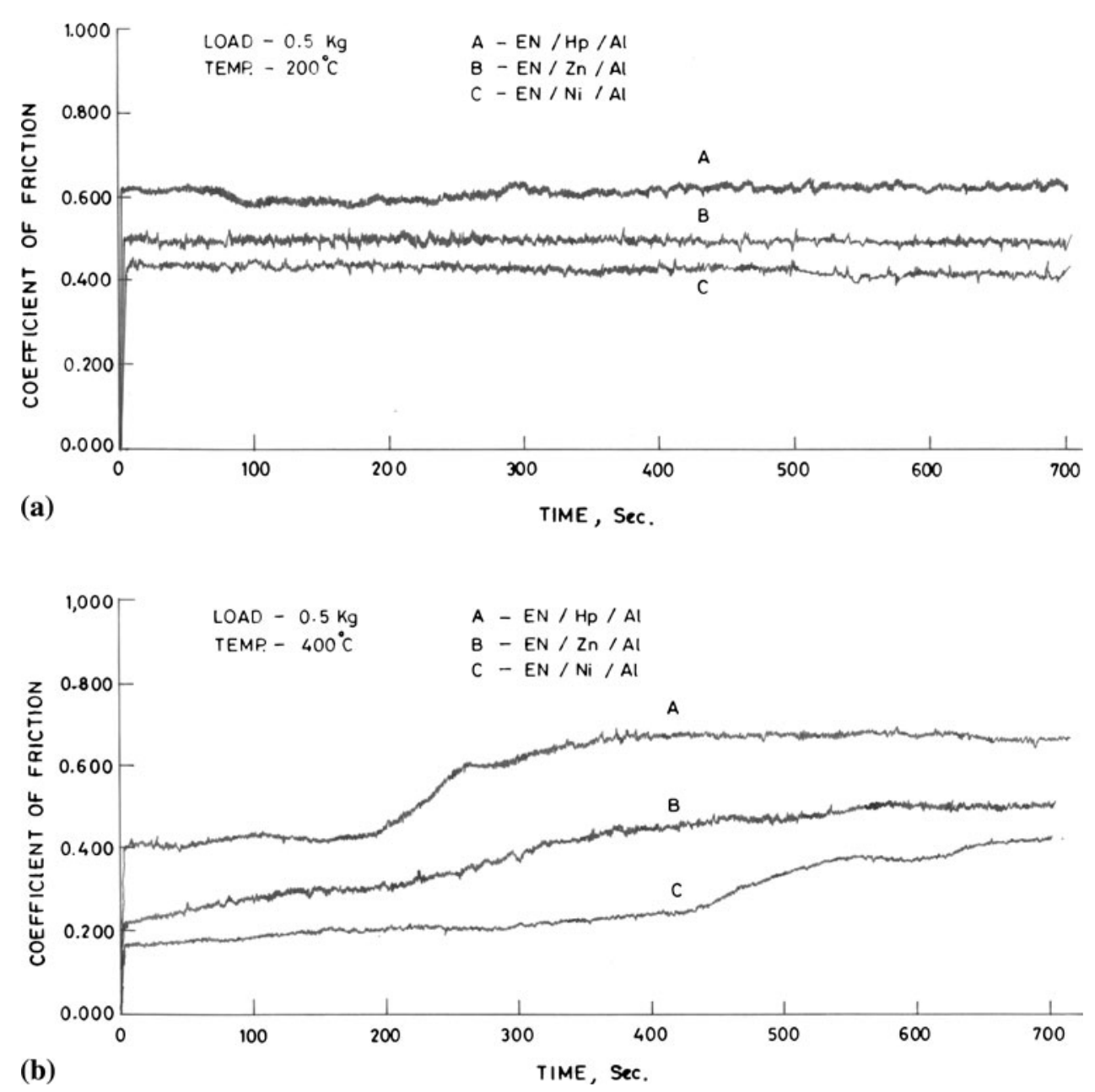

Fig. 3 Friction co-efficient of electroless Ni-P (h) deposits heat treated at (a) $200{ }^{\circ} \mathrm{C} / \mathrm{h}$ and (b) $400{ }^{\circ} \mathrm{C} / \mathrm{h}$ as a function of sliding time 

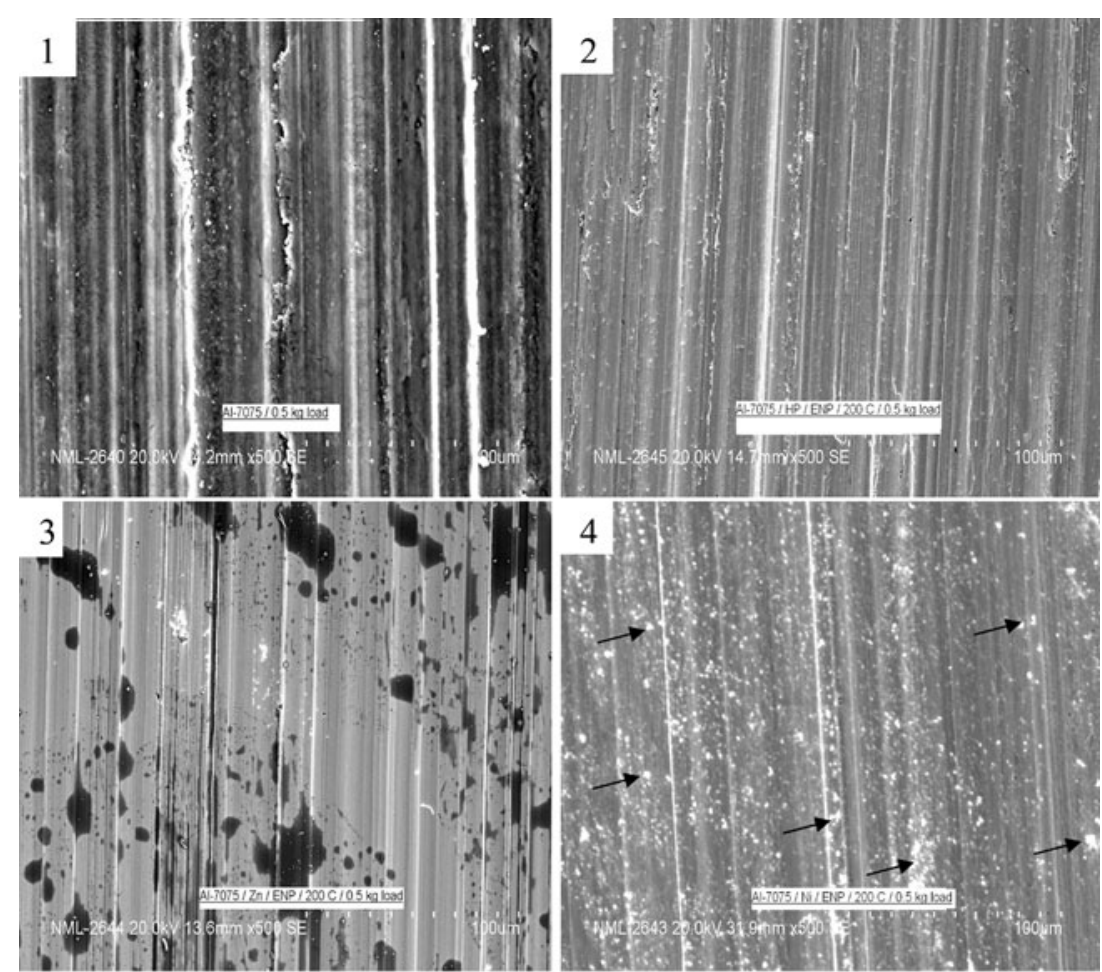

(a)
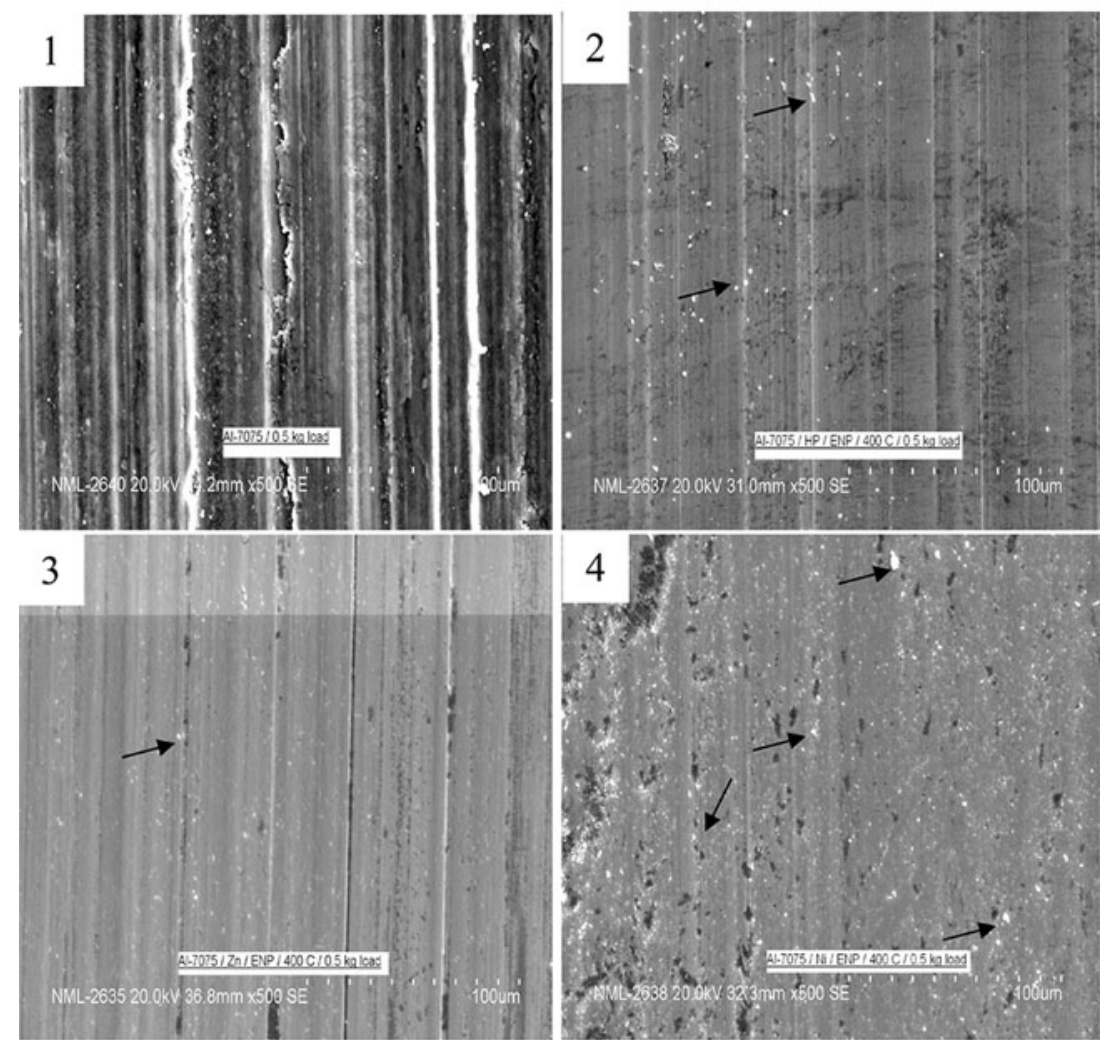

(b)

Fig. 5 SEM photographs of the worn surface of the $7075 \mathrm{Al}$ alloy substrate surface and EN coated samples of (a) $200{ }^{\circ} \mathrm{C}$ and (b) $400{ }^{\circ} \mathrm{C}$ with $0.5 \mathrm{~kg}$ load. In both (a) and (b): (1) $7075 \mathrm{Al}$ alloy substrate surface; (2) EN coated sample with HP pretreatment; (3) EN coated sample with Zn pretreatment; and (4) EN coated sample with Ni pretreatment 
$\sim 60 \mu \mathrm{m}$ in negative wear for $\mathrm{EN} / \mathrm{Ni} / \mathrm{Al}$ specimen with $400{ }^{\circ} \mathrm{C}$ and $0.5 \mathrm{~kg}$ load condition. It is shown in Fig. 5(a) that the roughening of the surface of the pretreated $\mathrm{Ni}$ enhances the strong interlocking between EN and $\mathrm{Al}$ alloy and the good adhesion between $\mathrm{EN} / \mathrm{Ni}$ and $\mathrm{Ni} / \mathrm{Al}$ is the reason for good wear performance. Finally, the emphasis in all the cases is that the $\mathrm{EN} / \mathrm{Ni} / \mathrm{Al}$ specimen with heat treatment $\left(400^{\circ} \mathrm{C}\right)$ exhibits better wear resistance than other pretreated samples in all conditions.
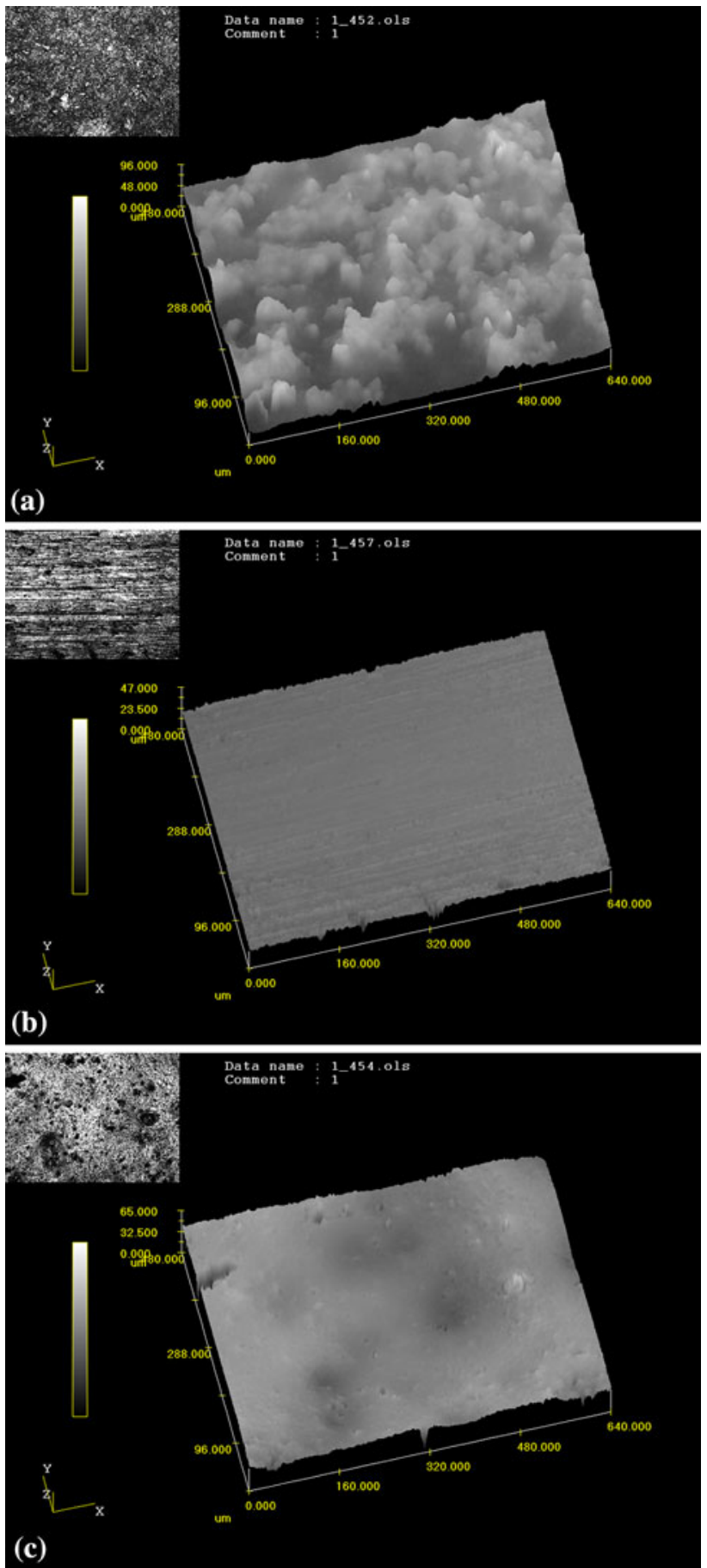

Fig. 6 3D images of (a) Ni strike pretreated on 7075 Al substrate, (b) zinc immersion pretreated on $7075 \mathrm{Al}$ substrate, and (c) HP absorbed layer pretreated on $7075 \mathrm{Al}$ substrate
The friction coefficient recorded simultaneously during the wear test clearly reveals the characteristics of the wear process. The average friction coefficient, $\mu_{\mathrm{av}}$ of electroless Ni-P (h) coatings in same load $(0.5 \mathrm{~kg})$ condition, is shown in Table 3 . The average friction coefficient at $400{ }^{\circ} \mathrm{C}\left(\mu_{\mathrm{av}}\right)$ had minimum value as compared to $200{ }^{\circ} \mathrm{C}$ specimens. The friction coefficient for electroless nickel versus steel is $\sim 0.12$ to 0.13 for lubricated conditions and 0.43 to 0.44 for unlubricated conditions (Ref 16). Krishnaveni et al. (Ref 17) had studied coefficient of friction (Ni-B (h)). These investigations showed that friction coefficient of Ni-B (h) was $\sim 0.7$ against hardened steel. The pretreatment had significant influence on the frictional properties. The relationship between the coefficient of friction and the sliding distance of electroless Ni-P (h) deposits, heat treated at 200 and $400{ }^{\circ} \mathrm{C}$ for $1 \mathrm{~h}$, is shown in Fig. 3(a) and (b). There is an initial sudden and abrupt increase of friction coefficiency, and then after some distance it stabilizes. This signifies the removal of the deposit and the onset of a friction process between the deposit pin and counter disc. The stability of $400{ }^{\circ} \mathrm{C}$ samples was started after $400 \mathrm{~s}$; this was due to lack of sample flatness. Hardness test was done for the as-deposited and heat-treated specimens; at least six runs were performed and averaged. The hardness of the as-deposited Ni-P coating was about $550 \mathrm{VHN}$, which is much higher than that of the 7075 aluminum alloy substrate (about $150 \mathrm{VHN}$ ). Heat treatment (Ni-P (h)) causes these alloys to have a value as high as 1000 to $1100 \mathrm{VHN}$, which is equivalent to most commercial hard chromium coatings. This is due to the heattreatment temperature of $400{ }^{\circ} \mathrm{C}$ enhancing the micro-crystalline phase in the EN deposit and thus increasing its hardness (Fig. 4). The Vicker's hardness results are 1065, 1040 and 1015 VHN for $\mathrm{Ni}, \mathrm{Zn}$ and $\mathrm{HP}$ pretreatments respectively at $400{ }^{\circ} \mathrm{C} / \mathrm{h}$ condition compared to $550 \mathrm{VHN}$ in as-deposit condition.

\subsection{Morphology and Components of EN Wear Track}

The SEM images of electroless Ni-P (h) deposits subjected to pin-on-disc wear test clearly revel the presence of groove patches and in some places even debris detachment is shown in Fig. 5(a) and (b). The transferred debris from coatings and the wear debris are also observed on the surface. The counter disc debris is also observed and indicated by arrows in Fig. 5. These results clearly demonstrate that the hardened steel has been

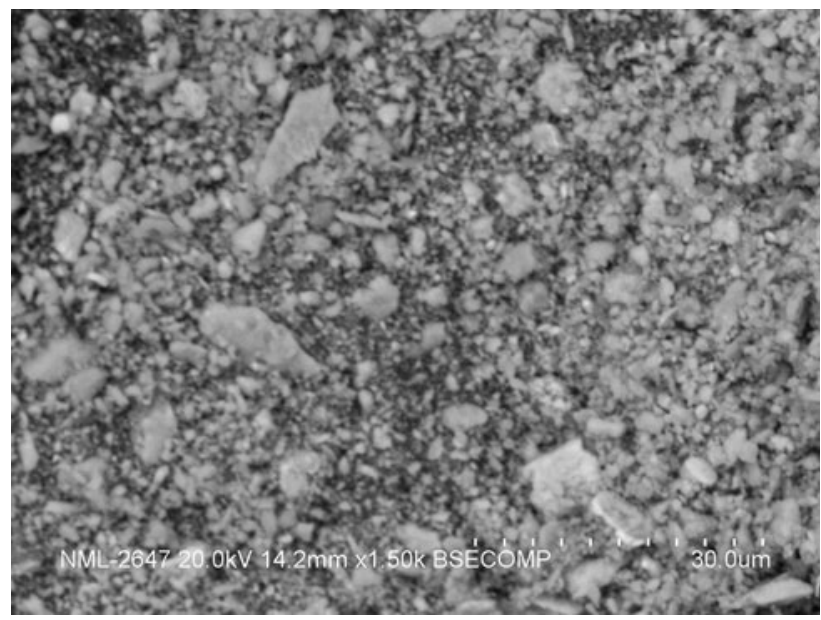

Fig. 7 SEM photo of worn debris 


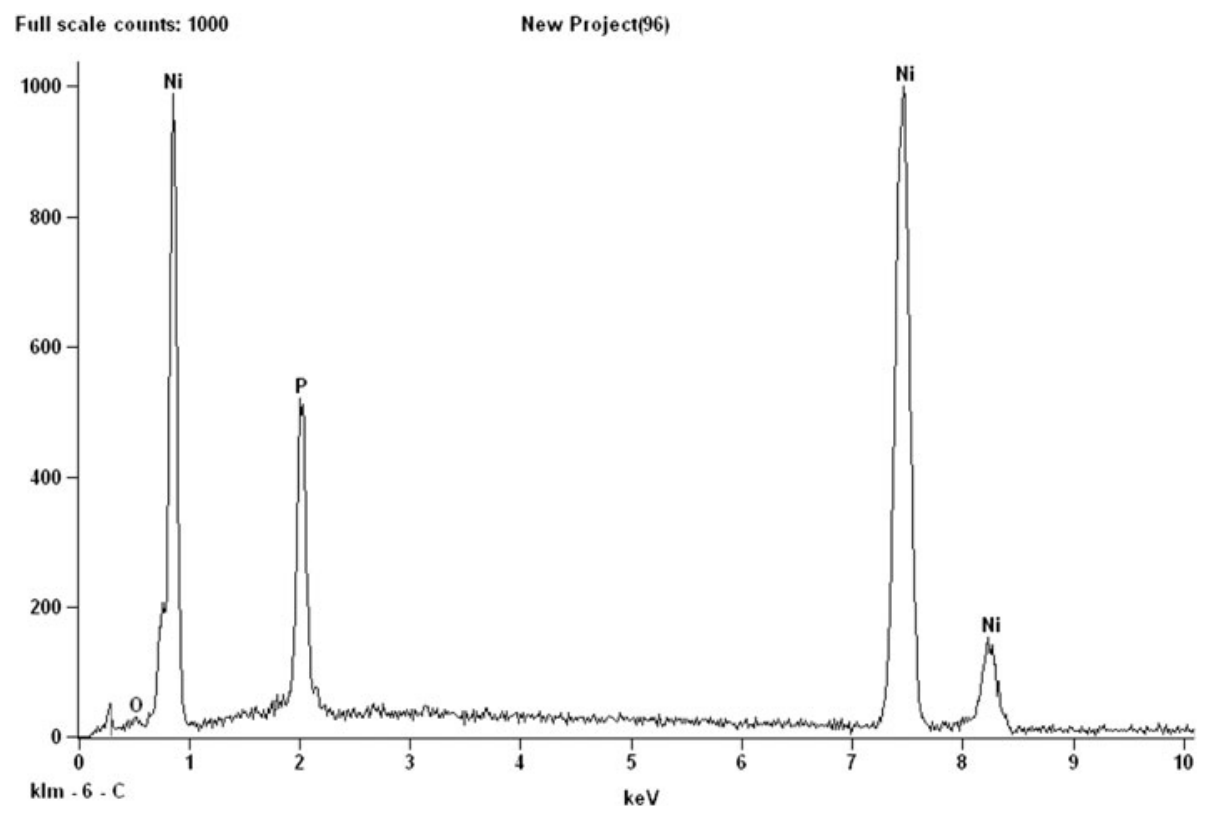

Fig. 8 EDAX pattern of EN coated on $7075 \mathrm{Al}$ substrate

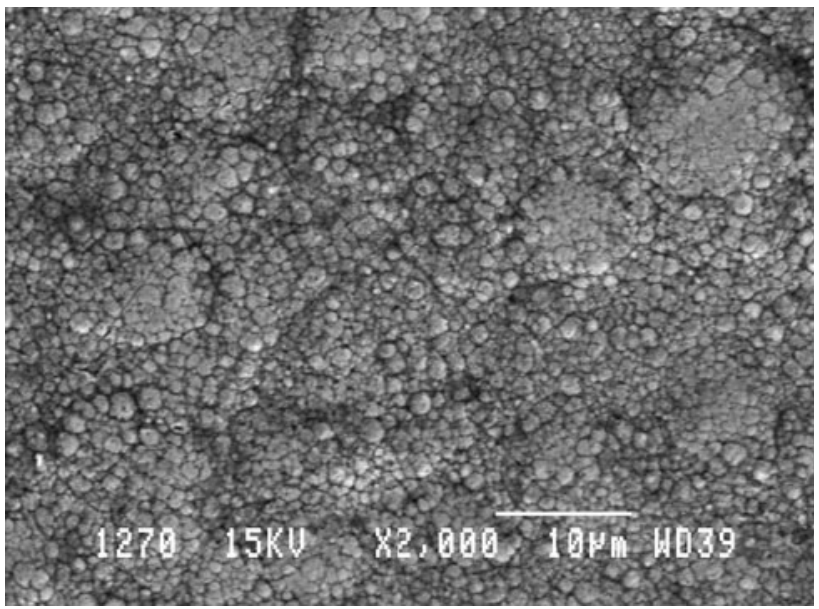

Fig. 9 SEM image of etched EN heat-treated sample $\left(400{ }^{\circ} \mathrm{C} / \mathrm{h}\right)$ on $7075 \mathrm{Al}$ substrate

removed during the slid wear test when the EN is abraded against the steel disc. The grooves distance in SEM images (Fig. 5a) measured that as-cast $\mathrm{Al}$ was higher and deeper, while EN were less and shorter and the same case is observed in Fig. 5(b). The confocal laser scanning microscope 3D images of three different pretreatment (without EN) clearly reveals the roughening surface of the pretreated Ni strike (Fig. 6a). This will enhance the strong interlocking between $\mathrm{EN}$ and $\mathrm{Al}$ alloy. On the other hand, zinc and HP show comparatively smooth surface (Fig. 6b, c). The SEM studies on the debris confirm the presence of $\mathrm{Fe}$ and $\mathrm{Mn}$ that suggest that debris comes out from the steel counter surface (Fig. 7). The as-cast $7075 \mathrm{Al}$ substrate showed severe damages by wear, whereas Ni-P (h) were less affected; this was clearly revealed by the SEM photo. The SEM/EDAX microanalysis carried out across the specimen surface (Fig. 8) showed the fluctuation of the phosphorus content within $7-8 \%$, so the microstructure should be a mixture of amorphous and microcrystalline phase. Figure 9 confirms that heating the sample up to $400{ }^{\circ} \mathrm{C} / 1 \mathrm{~h}$ induced the transformation of amorphous to microcrystalline phase and thus enhances its mechanical properties. The thickness of the EN deposits could also be measured on the SEM images taken on the cross-section of some representative samples. It is concluded that $\mathrm{Ni}$ strike pretreatment specimens noticeably improve the wear, frictional and hardness behavior of the EN coatings on $7075 \mathrm{Al}$ substrate and further enhanced it by heat treatment of $400{ }^{\circ} \mathrm{C} / \mathrm{h}$.

\section{Conclusions}

$\mathrm{Zn}$ (zincate), Ni strike and absorbed hypophosphite (HP) layer were used as the pretreated layers for the electroless Ni-P alloy on the 7075 aluminum alloy substrate. The layer enhances the wear properties of substrate and influences the frictional properties between substrate and the Ni-P phase. From the point of both the wear, frictional and hardness properties of the EN layers, the following conclusions are drawn.

- All the pretreated coatings improve the wear behavior of the 7075 aluminum alloy substrate. The wear behavior of EN mostly depends on the pretreatment conditions. Heattreatment temperature of $400{ }^{\circ} \mathrm{C}$ showed superior wear resistance properties of all types of pretreatment condition samples.

- The remark that is emphasized in all the cases is that the $\mathrm{EN} / \mathrm{Ni}$ deposit on $7075 \mathrm{Al}$ substrate shows noticeably enhanced wear resistance, high hardness and improved frictional behavior among the three different pretreatments and these properties were further enhanced by heat treatment at $400{ }^{\circ} \mathrm{C} / \mathrm{h}$. Furthermore, the beneficial effect of three pretreatments was estimated according to their wear performance as: $\mathrm{Ni}$ strike $>\mathrm{Zn}$ immersion $>\mathrm{HP}$ absorbed layer. 


\section{Acknowledgments}

The authors thank Prof. S.P. Mehrotra, Director, NML, Jamshedpur, for his kind permission to publish this paper. We are thankful to Mr. M.K. Gunjan and Mr. Y.P.K. Rao, technical officers, NML, Jamshedpur, and Mrs. Liu li hua, Jilin University, for SEM study, engineering drawing and laser scanning microscope support respectively.

\section{Open Access}

This article is distributed under the terms of the Creative Commons Attribution Noncommercial License which permits any noncommercial use, distribution, and reproduction in any medium, provided the original author(s) and source are credited.

\section{References}

1. A. Brenner and G.E. Riddell, Proceedings of the American Electroplaters' Society, Vol 33, 1946

2. A. Brenner and G.E. Riddell, Proceedings of the American Electroplaters' Society, Vol 34, 1947

3. S. Armyanov, T. Vangelova, and R. Stoyanchev, Pretreatment of Al-Mg Alloys for Electrodeposition by Immersion Zinc and Electroless Nickel, J. Surf. Technol., 1982, 17, p 89-100

4. P.H. Lo, W.T. Tsai, J.T. Lee, and M.P. Hung, Role of Phosphorus in the Electrochemical Behavior of Electroless Ni-P Alloys in $3.5 \mathrm{wt} \% \% \mathrm{NaCl}$ Solutions, J. Surf. Coat. Technol., 1994, 67, p 27

5. G.O. Mallory and J.B. Hajdu, Electroless Plating, Noyes Publications/ William Andrew Publishing, LLC, New York, 1996, p 35-55
6. J. Sudagar, M.K. Gunjan, and T.B. Singh, Proceedings of the 14th National Congress on Corrosion Control, Hyderabad, India, 18-20 Sept 2008

7. J.B. Hajdu, Plating Surf. Finish, 1996, 83, p 29

8. Z. Guo, K.G. Keong, and W. Sha, Crystallisation and Phase Transformation Behaviour of Electroless Nickel Phosphorus Platings During Continuous Heating, J. Alloys Compd., 2003, 358, p 112119

9. O.A. Leon, M.H. Staia, and H.E. Hintermann, Wear Mechanism of Ni-P-BN (h) Composite Autocatalytic Coatings, J. Surf. Coat. Technol., 2005, 200, p 1825-1829

10. A. Ramalho and J.C. Miranda, Friction and Wear of Electroless NiP and NiP + PTFE Coatings, J. Wear, 2005, 259, p 828-834

11. E.S. Puchi-Cabrera, C. Villalobos-Gutiérrez, I. Irausquin, J. La Barbera-Sosa, and G. Mesmacque, Fatigue Behavior of a 7075-T6 Aluminum Alloy Coated with an Electroless Ni-P Deposit, Int. J. Fatigue, 2006, 28, p 1854-1866

12. S. Wernick, R. Pinner, and P.G. Sheasby, The Surface Treatment and Finishing of Aluminum and Its Alloys, Vol 1, 5th ed., ASM International, Materials Park, 1996, p 2-4

13. D. Takács, L. Sziráki, T.I. Török, J. Sólyom, Z. Gácsi, and K. Gál-Solymos, Effects of Pre-treatments on the Corrosion Properties of Electroless Ni-P Layers Deposited on $\mathrm{AlMg}_{2}$ Alloy, J. Surf. Coat. Technol., 2007, 201, p 4526-4535

14. G.W. Stachowiak and A.W. Batchelor, Engineering Tribology, Butterworth-Heinemann, Boston, 2001, p 535

15. K. Venkateswarlu, A.K. Ray, M.K. Gunjan, L.C. Pathak, and D.P. Mondal, Tribological Wears Behavior of Diamond Reinforced Composite Coating, Mater. Sci. Eng. A, 2006, 418, p 357-363

16. J.P. Randin and H.E. Hintermann, Plating, 1967, 54, p 523

17. K. Krishnaveni, T.S.N. Sankara Narayanan, and S.K. Seshadri, Electroless Ni-B Coatings: Preparation and Evaluation of Hardness and Wear Resistance, J. Surf. Coat. Technol., 2005, 190, p $115-121$ 